IJHER International Journal of Humanities and Educational Research ISSN: 2757-5403

Volume 4, Issue 1, February 2022

Received: $24 / 10 / 2021$

Accepted: $12 / 12 / 2021$

Published: 01/02/2022

\title{
LANGUAGE CULTURE AND VARIABILITY IN SPEECH COMMUNITY
}

\author{
Dahmani MAMA 1 \\ Dr, University of Ahmed DRAIA, Algeria \\ Mahieddine RACHID ${ }^{2}$ \\ Dr, University of Ahmed DRAIA, Algeria
}

\begin{abstract}
Throughout these papers I intend to expose that language like the other forms of social activity has to be appropriate to the speaker using it. It also needs to be suitable for a particular situation and occasion according to the important social factors field, mode and tenor. This variability is a normal feature of language; for this reason we have not the right to blame any one since each established his language to satisfy the needs of his mind.

Linguistically speaking, we can not study language without referring it to society which uses it since the study of language without referring it to society is to exclude the possibility of finding social explanations for the structures that are used. It also needs to be added that language is not a simple code used by all people in societies but it differs from a person to another, from a social class to another, from a region to another, an ethnic group to another.

It is through this paper that I will try to show and elucidate the contribution of some of these factors in language variability in speech community showing in the meantime the strong connection between language and society.
\end{abstract}

Key words: language, Culture, Semiotics, Speech.

http://dx.doi.org/10.47832/2757-5403.12.5

1 (D) mimidah18@univ-adrar.edu.dz, https://orcid.org/0000-0003-3150-9056 


\section{Introduction:}

Sociolinguistics as a branch of linguistics tends to study the ways in which language is integrated with human society. The topic of language variation and its relation to different factors (regional, social) belongs to this branch of linguistics. Thus, the study of variation is very interesting to know people's origin through their speech community.

The word language can be defined as a system used by people to express their thoughts, emotions, feelings and ideas. We can not study language without referring it to society that uses it, where we live and there is no existence of society without language. That is to say language is part of society's culture.

Basically speaking, there is a strong correlation exists between society and language or between language organization and society. This relation reflects the attitudes of people toward other people including of course the cultural notms, context on the way language is used and the effect of any language use on society.

Language variability shows that language plays a very important role in conveying information about the speaker and it has a social function in establishing and maintaining social relationship. ${ }^{3}$

Sociologically speaking, society is divided into groups, each group is characterized by common interests and may have distinctive culture and institutions an as a result language creates society, it is language that brings people together.

In addition to that, there is no society without the existence of language, but also there is no study of language without reference to its society. and aspects of linguistic behaviour are reflections of the fact that there is a close inter-relationship between language and society.

\section{Historical background}

It is obvious that the national and official language in Algeria is Arabic. However, if we listen to the Algerian daily speech in general, wedistinguish the use of other languages, especiallyFrench which is widely spread in the Algerian society.

The French language is spoken by a large portion of the Algerian population. Many centuries go; Algeria witnessed the coming of different people with different cultures.

In the sixteenth century, another domination of the Spanish one, aimed at colonizing some Algerian territories (Oran, Miliana, Tenes, Mostaghanem, Tlemcen...) which somehow influenced the daily speech of the Algerians and this continuous even in the present-day Algeria. For instance, in the region of Ghazaouat, near Tlemcen people say BOTé which means boat in Spanish ${ }^{4}$.

But at that time the Turks, who reached theAlgerian coasts, in order to save the Algerians from the Spanishinvasion, brought with them the Turkish language and introducing some lexical terms.

The Maghreb in general and Algeria in particular, knew an increasing political instability because of the multiple dynasties such as those of Phoenicians, The Byzantines bringing with them new popultations, regimes and languages.

The social situation was made of different linguistic communities, theAlgerians have not lost their religion Islam which was deeply rooted in Algeria, and its Arabic language had to be preserved.

\footnotetext{
${ }^{3}$ Ana Huerta-Macias, code switching, bilingualism and illiteracy 1980.

${ }^{4}$ David Cristal (1999) the Cambridge encyclopedia of English language
} 
In 1830, the French people invaded Algeria to rule, takecontrol and colonize the country 5 .

The French military authorities occupied Algeria and gradually introduced the French language that would disturb the linguistic structure of the Algerian Arabic-speaking country.

Therefore, two communities were defeated, with which language did they communicate? Finally, what were the consequences of French on the Algerian community?

Before French colonialism, Arabic, the language of Islam, established a linguistic harmony in Algeria, but the French language disorganized gradually the sociolinguistic situation of the Algerian people.

Hence, the French policy imposed the use of French as the official language, this is why an important number of pedagogues were sent to Algeria in order to point education to implant the French language.

The main objective of France was to replace slowly Arabic by French; In this respect The Duke of Rovigo says:(1832)

"Le vrai prodige a opérer serait de remplacer peu a peu l'arabe par la langue Française ..."6

Although, the situation of the Algerians was made of two different linguistic communities, Arabic did not disappear and the great goal of France during the last years of colonization was total assimilation. In 1954, the Algerian people revolted against the French, and after a long armed struggle, Algeria obtained independence in 1962. However the consequences on more than a century of French domination were considerable on the daily speech of Algerians who use two languages and a certain tendency was created known as bilingualism.

It is clear that the association of these two languages is very interesting, seeing that French is an Indo-European language and Arabic a Semitic one, two quite different origins and completely divergent civilizations and cultures Arabo-Muslim VsChristiano European.

The regular relationship between French users and Arabic ones, which existed during colonialism, and still exist nowadays, has been a strong linguistic impact.

However, the coexistence of two different communities speaking two different languages allowing a direct communication with no respect of either the Arabic grammatical rules or the French ones ${ }^{7}$.

The vocabulary of Algerian Arabic relies on many borrowed words from French language; these French words are used by the Algerian people in almost all kinds of their daily conversation. the borrowed words are accommodated phonologically and morphologically to the Algerian dialect.

Some would say that we are not talking about the French vocabulary but about that of Algerian Arabic, but if we analyse such words, we will find them in different languages and mainly the French language. here are some French words that seem to be Arabic.

\footnotetext{
${ }^{5}$ David Cristal (1999) the Cambridge encyclopedia of English language

${ }^{6}$ James M. Anderson (1991) the linguistic encyclopedia edited by Kristen Malmkjar.london and New York by rout ledge.

${ }^{7}$ Tagmikhaled, the aspect of Algerian bilingualism, university of Tlemcen 2001-2002.
} 


\begin{tabular}{|l|l|}
\hline Words in French & Words in A.A \\
\hline Par-dessus & Bardso \\
\hline Batiment & Batéma \\
\hline Trottoir & Trottoir \\
\hline Pilier & Pili \\
\hline Lampe & lamba \\
\hline Bicyclette & Biciclita \\
\hline Banque & Banca \\
\hline Marché & Marché \\
\hline Terrain & Terrain \\
\hline Table & Tabla \\
\hline & \\
\hline
\end{tabular}

The study of the Algerian Arabic reveals the accommodation of French words at different linguistic levels. that is to say, some modifications are essential since the two languages diverge in their grammatical rules, phonemes and morphemes.

On the morphological level, the French language has some consonants that do not exist in theArabic language, such as $\mathrm{V}$ and $\mathrm{P}$, thus, these sounds are substituted by the nearest sounds in terms of articulation which are $\mathrm{F}$ and $\mathrm{B}$, for instance the word Villagebecame Fillageand paquetbecame baki .

\section{Conclusion}

In Algeria, the French language was imposed as the official language of administration and the government during the colonial rule. It is obvious that after such a long period of time, the daily speech of Algerians became not only influenced but also dominated by the French language

The Algerian bilingualism is the result of this historical process and geographically speaking, the spread of French was concentrated in the north of Algeria but this does not mean that all people in that area were inevitably bilingual. On the contrary, there are monolinguals, bilinguals and even trilingual those speakers mastering Arabic, French and Berber.

\footnotetext{
${ }^{8}$ - Peter Trudgill (1974) sociolinguistics, an introduction to language and society.penguin books.
} 


\section{Bibliography}

Ana Huerta -Macias, code switching, bilingualism and illiteracy 1980.

David Cristal (1999) the Cambridge encyclopedia of English language.

R.A Hudson, sociolinguistics, Oxford University press 1980.

James M. Anderson (1991) the linguistic encyclopedia edited by Kristen Malmkjar.london and New York by rout ledge.

Tagmikhaled, the aspect of Algerian bilingualism, university of Tlemcen 2001-2002.

Peter Trudgill (1974) sociolinguistics, an introduction to language and society.penguin books. 